\title{
THE TERAHERTZ EMISSION AND PHOTOELECTRON SPECTROSCOPY STUDY OF CuInS 2 THIN FILMS
}

\author{
S. Balakauskas ${ }^{\text {a }}$, A. Koroliov ${ }^{\text {a }}$, S. Grebinskij ${ }^{\text {a }}$, M. Senulis ${ }^{\text {a }}$, K. Sliužienè ${ }^{\text {a }}$, V. Lisauskas ${ }^{\text {a }}$, \\ S. Mickevičius ${ }^{a}$, and R.L. Johnson ${ }^{b}$ \\ a Center for Physical Sciences and Technology, Savanoriu 231, LT-02300 Vilnius, Lithuania \\ E-mail: bsaulius@pfi.lt \\ b Hamburg Synchrotron Radiation Laboratory HASYLAB at German Electron Synchrotron DESY, Notkestrasse 85, \\ D-22603 Hamburg, Germany
}

Received 29 August 2011; accepted 20 September 2012

\begin{abstract}
$\mathrm{CuInS}_{2}$ thin films were produced by a two-stage process by means of the sulfurisation of magnetron-sputtered metallic precursor layers on molybdenum-covered soda-lime glass substrates. Terahertz pulse generation from the surface of $\mathrm{CuInS}_{2}$ thin films excited by femtosecond laser pulses was studied. Terahertz radiation efficiency is dependent on the stoichiometry of the films obtained. The interface formation between vacuumevaporated $\mathrm{CdS}$ and $\mathrm{CuInS}$ thin films was studied by photoelectron spectroscopy using synchrotron radiation. The valence band offset of $0.7 \pm 0.1 \mathrm{eV}$ was determined for the $\mathrm{CdS} / \mathrm{CuInS}_{2}$ heterojunction.
\end{abstract}

Keywords: thin film, $\mathrm{CuInS}_{2}$, photovoltaic absorbers, sulfurisation, terahertz radiation, photoelectron spectroscopy

PACS: 68.35.Ct, 79.60.Dp, 79.60.Jv, 88.40.jn

\section{Introduction}

$\mathrm{CuInS}_{2}$ (CIS) with the band gap value of $1.5 \mathrm{eV}$ and its high absorption coefficient of almost $10^{5} \mathrm{~cm}^{-1}$ is representing an important class of the recently developed light absorbers for highly efficient and lowcost solar cells [1-3]. Recent studies have shown that CIS solar cell efficiency ranges from 10.2 to $12.3 \%$ [4-5]. Many processing techniques for the preparation of $\mathrm{CulnS}_{2}$ thin films have been extensively studied in order to fabricate cheaper devices [6-9]. One of the most commonly used methods is a two-step process. The first step is the production of a precursor $\mathrm{Cu}$-In film by evaporating [10] or sputter deposition [11] in a vacuum system. In the second step, the precursor film is placed in a sulfurisation furnace filled with $\mathrm{H}_{2} \mathrm{~S}$ gas or elemental sulfur vapour for the formation of a CIS film. In this study, we have prepared CIS thin films by DC sputtering from the $\mathrm{Cu}$-In target with successive sulfurisation in elemental sulphur vapour.

The band discontinuities between the CIS absorber and CdS buffer layer are critical for solar cell efficiencies. The offset itself can vary depending on the crystallinity and stoichiometry of the CIS absorber and the method of junction preparation. Photoelectron spectroscopy is widely used to determine valence band offsets in semiconductor heterojunctions. In this study, the interface formation between vacuum-evaporated CdS and CIS thin films has been studied by electron photoemission using synchrotron radiation.

The second object of the study was terahertz pulse generation from the surface of the thin films exited by femtosecond laser pulses. Photoexited electrons and holes are separated by the built-in 
field at the surface of the semiconductor, which produces fast-changing current transients and leads to radiation at $\mathrm{THz}$ frequencies. A strong internal field is responsible for $\mathrm{THz}$ emission from the surface of I-III-VI 2 compounds [12]. This field also leads to the separation of charge carriers in solar cells. So, the stimulated terahertz emission can be used as a non-destructive and contact-free method for the characterisation of thin film absorbers for solar cells. In this paper we present the results of the study of THz emission efficiency on CIS stoichiometry and surface preparation.

\section{Experiment}

CIS thin films were produced by the sulfurisation of DC magnetron-sputtered metallic precursor layers on molybdenum-covered soda-lime glass substrates. The sputtering was performed in $\mathrm{Ar}^{+}$at the pressure of about $2 \mathrm{~Pa}$. The sputtering current was $30 \mathrm{~mA}$, voltage $550 \mathrm{~V}$. Under these conditions the deposition rate was $\approx 1.1 \AA /$ s. The films of about $1 \mu \mathrm{m}$ thickness were determined by profilometry. $\mathrm{X}$-ray diffraction analysis confirmed the formation of a single $\mathrm{CuInS}_{2}$ phase and the presence of minor secondary phases $\mathrm{Cu}_{2-x} \mathrm{~S}$.

The interface formation between vacuum-evaporated CdS and the CIS thin film experiment were performed in the synchrotron radiation laboratory HASYLAB, Hamburg (Germany). Synchrotron radiation obtained from the storage ring DORIS III was monochromatised with the FLIPPER II plane grating vacuum monochromator designed for the photon energy range of $15-200 \mathrm{eV}$. The spectrometer was equipped with a CMA electron energy analyser. The total energy resolution was kept at $0.1 \mathrm{eV}$. The origin of the energy axis was set at Fermi energy as measured for the reference Au sample. CdS was deposited from a Knudsen cell in the preparation chamber, and the evaporation ratio of about $1.0 \AA /$ min was determined using a quartz microbalance. After Shirley background [13] subtraction, complex photoelectron spectra were decomposed into separate peaks by specifying the peak position. The accuracy of the measured lines $\mathrm{BE}$ and relative intensities were about $0.1 \mathrm{eV}$ and $10 \%$, respectively.

$\mathrm{THz}$ radiation from the surface of CIS exited by laser pulses of $150 \mathrm{fs}$ duration and the average power of $220 \mathrm{~mW}$ was studied using the experimental set-up described in [12, 14$]$.

\section{Results and discussion}

In other works [12, 14] the observation of the efficient $\mathrm{THz}$ radiation from the surface of chalcopyrite I-III-VI ${ }_{2}$ compounds excited by femtosecond laser pulses has been reported. It has been found that terahertz radiation efficiency is critically dependent on the stoichiometry of $\mathrm{CuInSe}_{2}$ layers [12]. The THz transient magnitude increases monotonically when the $\mathrm{CuInSe}{ }_{2}$ layer composition gets closer to the stoichiometric composition. On the other side, the $\mathrm{CuInSe}_{2}$ monograin layer solar cell devices with different compositions of absorber material show a different behaviour of output parameters. Solar cell structures based on these absorber materials yield the highest values of efficiency, when the precursor $\mathrm{Cu}$-In alloy composition varies between $0.9<\mathrm{Cu} / \mathrm{In}<1$ [15]. It means that the efficiency of $\mathrm{THz}$ radiation from chalcopyrite could be useful for the characterisation of their eligibility in photovoltaic application. This study is the first step for the development of the above-mentioned method for the characterisation of materials.

Figure 1 shows $\mathrm{THz}$ pulse spectra obtained from the CIS layers with a different stoichiometry. The largest pulse amplitudes were obtained when the $\mathrm{Cu} / \mathrm{In}$ atomic ratio was about 0.9 . A much weaker $\mathrm{THz}$ emission from CIS thin films was observed at $\mathrm{Cu} / \mathrm{In}$ ratio $\leq 0.7$. It confirms that $\mathrm{THz}$ radiation efficiency depends on the stoichiometry of CIS films.

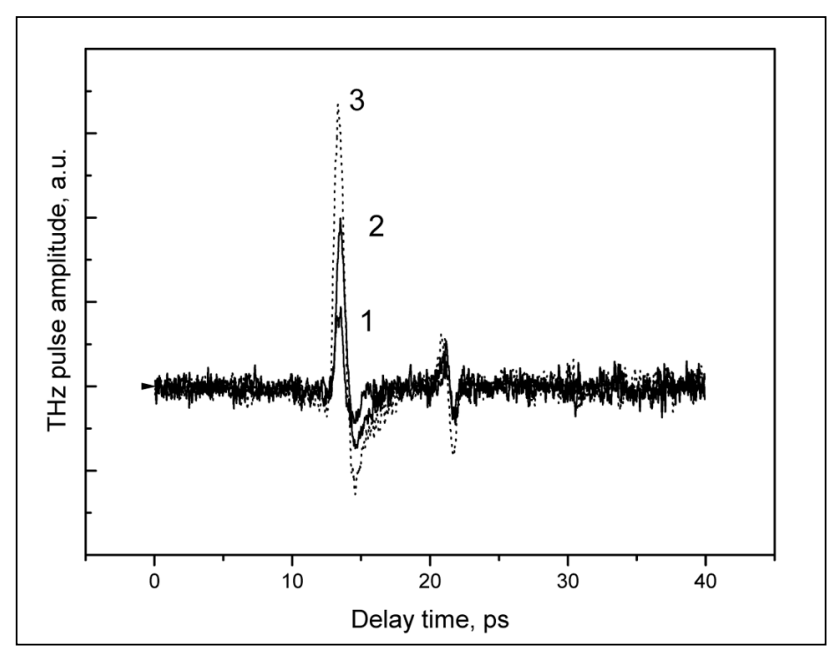

Fig. 1. THz pulse waveform, radiated by CIS, exited by femtosecond laser pulses at different $\mathrm{Cu} / \mathrm{In}$ atomic ratios: (1) 0.65 , (2) 0.79 , and (3) 0.9 . 
Photoelectron spectroscopy is widely used to determine valence band offsets of semiconductor heterojuctions. The valence band discontinuity $\Delta E_{\mathrm{v}}$ for a semiconductor heterojunction can be determined from binding energy differences of substrate and absorbate core levels where both substrate (CIS) and absorbate emissions are present (CdS layer thickness about 5-35 ̊). This procedure requires the knowledge of the core level binding energy with respect to the valence band maxima of either semiconductor. This quantity may be obtained from the theoretically calculated density of states or by fitting of the experimentally broadened leading edge of valence band emissions [16]. In this work, the valence band discontinuity was determined directly from the valence band difference spectra measured for different CdS coverage. The photoelectron spectra of CIS with different CdS coverage are shown in Fig. 2. The spectra were normalised to the valence band maximum for the guide for eyes. With increasing CdS thickness, the In $4 \mathrm{~d}$ intensity decreased, and Cd $4 \mathrm{~d}$ peaks intensity increased. It can be seen from Fig. 3 that after the coverage of $\mathrm{CdS}>7 \AA$, the difference between In $4 \mathrm{~d}$ and $\mathrm{Cd} 4 \mathrm{~d}$ centroids is saturated, indicating that the CIS surface is completely covered with the CdS layer.

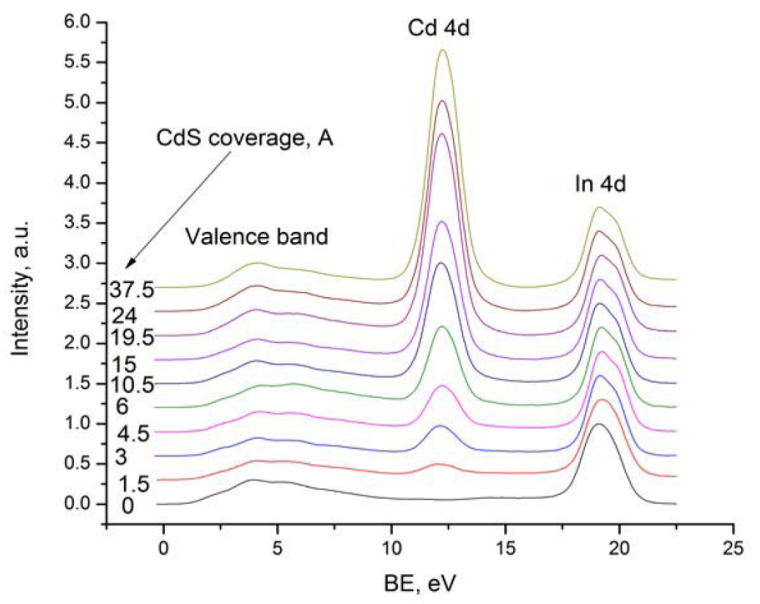

Fig. 2. Photoelectron spectra of In $4 d$, Cd $4 d$, and valence bands for $\mathrm{CuInS}_{2}$ film in the course of CdS deposition. Spectra are recorded with the excitation energy of $h v=80 \mathrm{eV}$ and normalised to the same In $4 \mathrm{~d}$ intensity for better visibility.

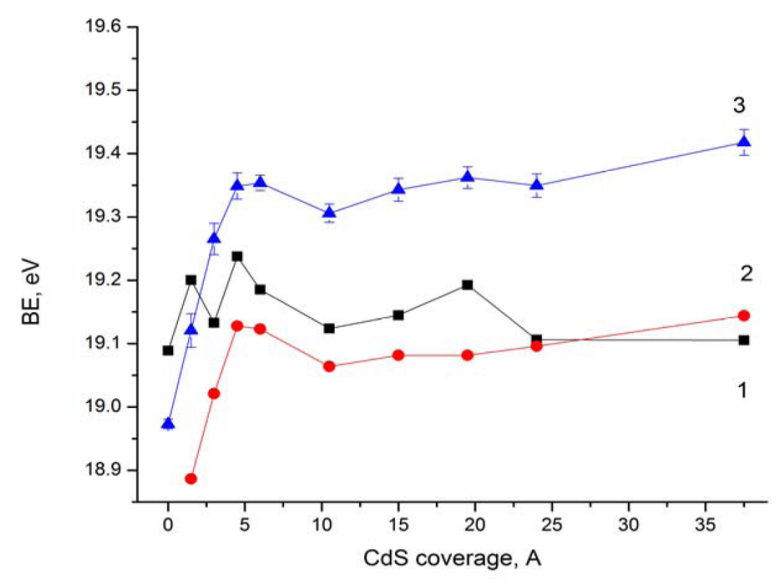

Fig. 3. Evolution of binding energies of (1) In $4 d,(2) \mathrm{Cd}$ $4 \mathrm{~d}$ centroids, and (3) $\mathrm{CuInS}_{2}$ film valence band maxima (VBM) in the course of CdS deposition. An offset of +6.9 and $+17.8 \mathrm{eV}$ is added to $\mathrm{Cd} 4 \mathrm{~d}$ and $\mathrm{VBM}$ binding energy value, respectively. Error bars denote the standard deviation of the VBM values obtained by linear fitting of the leading edge of the valence band emission.

Figure 4 illustrates the determination of the valence band offset between the CIS and CdS coverage. For the determination of valence band difference spectra corresponding to $\mathrm{CdS}$ valence band spectra, the normalisation of In $4 \mathrm{~d}$ intensities and coincidence of the binding energies (by values adopted from Fig. 3) for different CdS

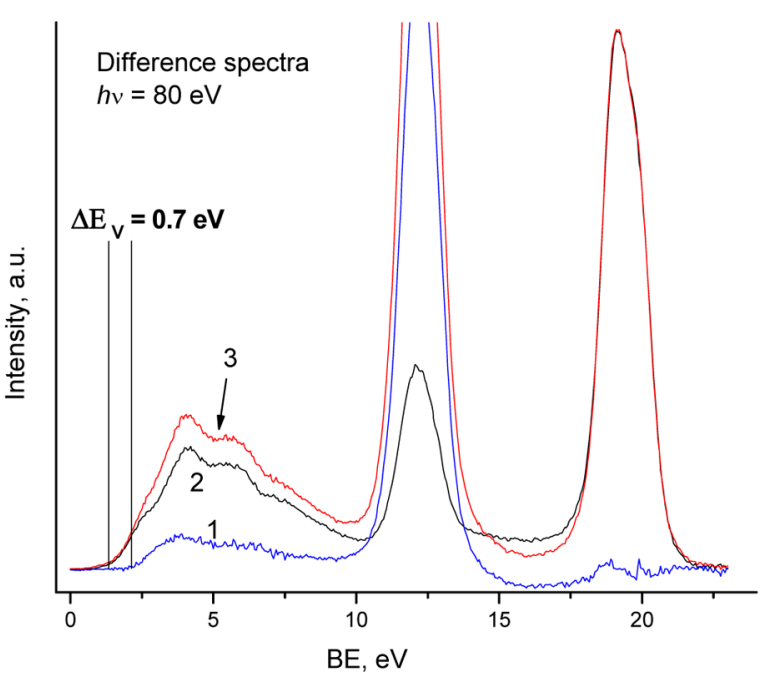

Fig. 4. Valence band difference spectra between (1) $\mathrm{CuInS}_{2}$ film covered with (2) 3 and (3) $10.5 \AA \mathrm{CdS}$. The spectra were normalised to the In $4 \mathrm{~d}$ core level. 
coverage were performed. The valence band offset $\Delta E_{\mathrm{v}} \approx 0.7 \pm 0.1 \mathrm{eV}$ determined from the linear extrapolation of the valence band maxima of CIS and $\mathrm{CdS}$ is presented in Fig. 4. This value is comparable with $\Delta E_{\mathrm{v}}=0.6 \mathrm{eV}$ (CdS deposited from Knudsen cell) [17], $1.18 \mathrm{eV}$, and $1.25 \mathrm{eV}$ [16, 18] (chemical bath deposited CdS) surface.

\section{Summary and conclusions}

CIS thin films were produced by means of the sulfurisation of DC magnetron-sputtered metallic precursor layers on molybdenum-covered soda-lime glass substrates. $\mathrm{THz}$ emission efficiency from the surfaces of thin $\mathrm{CuInS}_{2}$ films excited by femtosecond laser pulses was investigated. Terahertz radiation efficiency was strongly dependent on the stoichiometry of the films obtained and can be a useful tool for the characterisation of CIS absorbers. The valence band discontinuity $\Delta E_{\mathrm{v}}$ between the CIS thin film surface and thermally evaporated $\mathrm{CdS}$ was determined using photoelectron spectroscopy exited by synchrotron radiation. For CdS coverage larger than $7 \AA, \Delta E_{\mathrm{v}}$ is $0.7 \pm 0.1 \mathrm{eV}$.

\section{Acknowledgments}

This research was funded by a grant (No. ATE04/2010) from the Research Council of Lithuania.

\section{References}

[1] R. Klenk, J. Klaer, R. Scheer, M.Ch. Lux-Steiner, I. Luck, N. Meyer, and U. Ruhle, Solar cells based on CuInS 2 an overview, Thin Solid Films 480-481, 509-514 (2005).

[2] C. Guillen, CuInS 2 thin films grown sequentially from binary sulfides as compared to layers evaporated directly from the elements, Semicond. Sci. Technol. 21, 709-712 (2006).

[3] S.J. Roh, R.S. Mane, H.M. Pathan, O.-S. Joo, and S.H. Han, Rapid growth of nanocrystalline $\mathrm{CuInS}_{2}$ thin films in alkaline medium at room temperature, Appl. Surf. Sci. 252, 1981-1987(2005).

[4] R. Klenk, J. Klaer, Ch. Koble, R. Mainz, S. Merdes, H. Rodriguez-Alvarez, R. Scheer, and H.W. Schock, Development of $\mathrm{CuInS}_{2}$-based solar cells and modules, Sol. Energ. Mater. Sol. Cell. 95, 1441-1445 (2011).

[5] M. Gossla, Th. Hahn, H. Metzner, J. Conrad, and U. Geyer, Thin $\mathrm{CuInS}_{2}$ films by three-source mo- lecular beam deposition, Thin Solid Films 268, 3944 (1995).

[6] Y. Yamamoto, T. Yamaguchi, T. Tanaka, N. Tanahashi and A. Yoshida, Characterization of $\mathrm{CuInS}_{2}$ thin films prepared by sputtering from binary compounds, Sol. Energ. Mater. Sol. Cells 49, 399-405 (1997).

[7] Y.B. He, T. Kramer, A. Polity, M. Hardt, and B.K. Meyer, Influence of the preparation conditions on the properties of $\mathrm{CuInS}_{2}$ films deposited by one-stage RF reactive sputtering, Thin Solid Films 431-432, 126-130 (2003).

[8] T. Todorov, E. Cordoncillo, J.F. Sanchez-Royo, J. Carda, and P. Escribano, CuInS films for photovoltaic applications deposited by a low-cost method, Chem. Mater. 18, 3145-3150 (2006).

[9] I. Oja, M. Nanu, A. Katerski, M. Krunks, A. Mere, J. Raudoja, and A. Goossens, Crystal quality studies of $\mathrm{CuInS}_{2}$ films prepared by spray pyrolysis, Thin Solid Films 480-481, 82-86 (2005).

[10]M. Gossla, H. Metzner, and H.-E. Mahnke, Coevaporated $\mathrm{Cu}$-In films as precursors for solar cells, J. Appl. Phys. 86, 3624-3632 (1999).

[11] K. Siemer, J. Klaer, I. Luck, J. Bruns, R. Klenk, and D. Braunig, Efficient CuInS, solar cells from a rapid thermal process (RTP), Sol. Energ. Mater. Sol. Cell. 67, 159-166 (2001).

[12] R. Adomavičius, A. Krotkus, J. Kois, S. Bereznev, and E. Mellikov, Terahertz radiation from nonstoichiometric $\mathrm{CuInSe}_{2}$ films excited by femtosecond laser pulses, Appl. Phys. Lett. 87, 191104 (2005).

[13] D.A. Shirley, High-resolution X-ray photoemission spectrum of the valence bands of gold, Phys. Rev. B 5, 4709-4714 (1972).

[14]R. Adomavicius, A. Krotkus, R. Sustaviciute, G. Molis, J. Kois, S. Bereznev, E. Mellikov, and P. Gashin, Optoelectronic surface emitters of terahertz radiation from copper chalcogenides, Electron. Lett. 43, 1458-1459 (2007).

[15] M. Kauk, M. Altosaar, J. Raudoja, A. Jagomägi, M. Danilson, and T. Varema, The performance of $\mathrm{CuInSe}_{2}$ monograin layer solar cells with variable indium content, Thin Solid Films 515, 5880-5883 (2007).

[16]Y. Hashimoto, K. Takeuchi, and K. Ito, Band alignment at $\mathrm{CdS} / \mathrm{CuInS}$, heterojunction, Appl. Phys. Lett. 67, 980-982 (1995).

[17] A. Klein, T. Loher, Y. Tomm, C. Pettenkofer, and W. Faegermann, Band lineup between CdS and ultra high vacuum-cleaved $\mathrm{CuInS}$, single crystals, Appl. Phys. Lett. 70, 1299-1301 (1997).

[18] B. Johnson, L. Korte, T. Lußky, J. Klaer, and I. Lauermann, $\mathrm{CuInS}_{2}-\mathrm{CdS}$ heterojunction valence band offset measured with near-UV constant final state yield spectroscopy, J. Appl. Phys. 106, 073712-1-6 (2009). 


\title{
PLONŲJŲ CuInS ${ }_{2}$ SLUOKSNIŲ TERAHERCINĖS SPINDULIUOTĖS IR FOTOELEKTRONINĖS EMISIJOS TYRIMAS
}

\author{
S. Balakauskas a , A. Koroliov a, S. Grebinskij ${ }^{\text {a }}$, M. Senulis a ${ }^{\text {a }}$ K. Sliužienè a ${ }^{\text {, }}$ V. Lisauskas ${ }^{\text {a }}$, \\ S. Mickevičius ${ }^{a}$, R. L. Johnson ${ }^{\text {a }}$ \\ ${ }^{a}$ Fiziniu ir technologijos mokslu centras, Vilnius, Lietuva \\ ${ }^{\mathrm{b}}$ Vokietijos elektronu sinchrotronas (DESY), Hamburgas, Vokietija
}

\section{Santrauka}

$\mathrm{CuInS}_{2}$ plonieji sluoksniai buvo pagaminti sulfitizuojant magnetroninio dulkinimo būdu nusodintus sluoksnius ant molibdenu dengtų stiklo padèklų. Ištirtas terahercinių impulsų generavimas iš $\mathrm{CuInS}_{2}$ plonųjų sluoksnių paviršių, sužadintų femtosekundiniais lazerio impulsais. Terahercinès spinduliuotės efektyvumas pri- klauso nuo plonųjų sluoksnių stechiometrijos ir morfologijos. Sandūros formavimas tarp vakuume garinto $\mathrm{CdS}$ ir CuInS ${ }_{2}$ plonųjų sluoksnių buvo tiriamas rentgeno fotoelektronine spektroskopija naudojant sinchrotroninę spinduliuotę. CdS ir CIS valentinių juostų netolydumas yra tiesiogiai nustatytas iš valentinès juostos skirtuminių spektrų ir yra $\approx 0,7 \pm 0,1 \mathrm{eV}$. 